\title{
Unravelling the Genetic Basis of Primary Aldosteronism
}

\author{
Niki Mourtzi ${ }^{1}$, Amalia Sertedaki ${ }^{1}$, Athina Markou ${ }^{2}$, George P. Piaditis ${ }^{2}$ and Evangelia Charmandari ${ }^{1,3, *(1)}$ \\ 1 Division of Endocrinology, Metabolism and Diabetes, First Department of Pediatrics, National and \\ Kapodistrian University of Athens Medical School, "Aghia Sophia” Children's Hospital, \\ 11527 Athens, Greece; nikimourtzi23@gmail.com (N.M.); aserted@med.uoa.gr (A.S.) \\ 2 Department of Endocrinology and Diabetes Center, G. Gennimatas General Hospital, 11527 Athens, Greece; \\ amarkouuk@yahoo.co.uk (A.M.); edk-pgna@otenet.gr (G.P.P.) \\ 3 Division of Endocrinology and Metabolism, Center of Clinical, Experimental Surgery and Translational \\ Research, Biomedical Research Foundation of the Academy of Athens, 11527 Athens, Greece \\ * Correspondence: evangelia.charmandari@googlemail.com; Tel./Fax: +30-213-2013384
}

check for updates

Citation: Mourtzi, N.; Sertedaki, A.; Markou, A.; Piaditis, G.P.; Charmandari, E. Unravelling the Genetic Basis of Primary Aldosteronism. Nutrients 2021, 13, 875. https://doi.org/10.3390/ nu13030875

Academic Editor: Lindsay Brown

Received: 2 February 2021

Accepted: 4 March 2021

Published: 8 March 2021

Publisher's Note: MDPI stays neutral with regard to jurisdictional claims in published maps and institutional affiliations.

Copyright: (c) 2021 by the authors. Licensee MDPI, Basel, Switzerland. This article is an open access article distributed under the terms and conditions of the Creative Commons Attribution (CC BY) license (https:/ / creativecommons.org/licenses/by/ $4.0 /)$.

\begin{abstract}
Primary aldosteronism (PA), a condition characterized by autonomous aldosterone hypersecretion, constitutes the most common cause of secondary hypertension. Over the last decade, major breakthroughs have been made in the field of genetics underpinning PA. The advent and wide application of Next Generation Sequencing (NGS) technology led to the identification of several somatic and germline mutations associated with sporadic and familial forms of PA. Somatic mutations in ion-channel genes that participate in aldosterone biosynthesis, including KCNJ5, CACNA1D, $A T P 1 A 1$, and $A T P 2 B 3$, have been implicated in the development of aldosterone-producing adenomas (APAs). On the other hand, germline variants in CLCN2, KCNJ5, CACNA1H, and CACNA1D genes have been implicated in the pathogenesis of the familial forms of PA, FH-II, FH-III, and F-IV, as well as PA associated with seizures and neurological abnormalities. However, recent studies have shown that the prevalence of PA is higher than previously thought, indicating the need for an improvement of our diagnostic tools. Further research is required to recognize mild forms of PA and to investigate the underlying molecular mechanisms.
\end{abstract}

Keywords: primary aldosteronism; hypertension; cardiovascular disease; genetic causes of primary aldosteronism

\section{Introduction}

Hypertension is a major risk factor for the development of cardiovascular disease and its associated morbidity and mortality, and has been identified as the third leading cause of disability-adjusted life-years [1]. The global prevalence of hypertension for the year 2000 has been estimated to be $26.4 \%$ of the world population ( 976 million) and is expected to increase to $29 \%$ (1.56 billion) by 2025 , with tremendous implications for the health care system [2].

Primary Aldosteronism (PA), a condition characterized by autonomous aldosterone overproduction, was first described by Conn in 1955 and was considered to be a rare cause of hypertension with a prevalence of less than $1 \%$ among hypertensive patients. However, following the introduction of plasma aldosterone concentration to plasma renin activity ratio (ARR) as a screening test in clinical practice, it became evident that the prevalence of PA is higher than previously thought [3-5]. Currently, PA is recognized as the most common cause of secondary hypertension, accounting for $6.1 \%$ of hypertensive patients and up to $20 \%$ of patients with severe or treatment-resistant hypertension [6,7]. Early identification and treatment of patients with PA is of paramount importance because they have a higher risk of stroke, myocardial infarction, and atrial fibrillation than patients with essential hypertension matched for age, gender, and blood pressure [8].

Over the last years, with the advent of Next Generation Sequencing (NGS), major advances have been made in our understanding of the molecular mechanisms underlying 
autonomous aldosterone overproduction in both sporadic and familial forms of PA. The purpose of this review is to provide an update on the current knowledge on the genetics of PA.

\section{Evidence Favoring a Higher Prevalence of PA}

The traditional approach in the diagnosis of PA involves an initial screening procedure to identify patients with higher probability for PA (Table 1) [9], followed by the application of aldosterone-to-renin ratio (ARR) test to detect elevated concentrations of aldosterone. Patients with positive ARR undergo a confirmatory test (e.g., oral-sodium loading, salineinfusion test, fludrocortisone suppression test, captopril test) in order to confirm or exclude autonomous aldosterone secretion independent of the renin-angiotensin system (RAAS), and subsequently an adrenal computed tomography (CT) scan to investigate the existence of an adrenal mass (bilateral or unilateral) [10]. Following this approach, Monticone et al. reported a prevalence of PA between $3.9 \%$ and $11.8 \%$, depending on the severity of hypertension [11].

Table 1. The current recommendations of the Endocrine Society for Primary Aldosteronism screening.

The Current Recommendations of the Endocrine Society for Primary Aldosteronism Screening

- $\quad$ Sustained blood pressure (BP) above $150 / 100 \mathrm{mmHg}$ on each of three measurements obtained on different days

- Hypertension (BP > 140/90 mmHg) resistant, not controlled by three conventional antihypertensive drugs (including a diuretic)

- $\quad$ Controlled BP (<140/90 mmHg) on four or more antihypertensive drugs

- Hypertension and spontaneous or diuretic-induced hypokalemia

- Hypertension and adrenal incidentaloma

- Hypertension and sleep apnea

- Hypertension and a family history of early-onset hypertension or cerebrovascular accident at a young age ( $<40$ years).

- $\quad$ All hypertensive first-degree relatives of a patient with Primary Aldosteronism

However, compelling evidence suggests that PA is much more prevalent than previously thought, with a large number of PA cases remaining undiagnosed [12,13]. This is mainly attributed to the fact that current diagnostic tests based on plasma aldosterone and renin concentrations may be insufficient to identify mild forms of PA, especially if based on the arbitrary conventional ARR thresholds [11]. Piaditis and others [13,14] have shown that when PA screening is extended to all hypertensive patients, irrespectively of the ARR, the PA prevalence is 3-5 times higher than previously determined, ranging between $16 \%$ and $31 \%$ across the spectrum of mild to severe hypertension [13,14]. Critically, PA has been documented in $11 \%$ and $13 \%$ of apparently healthy normotensive and normokalemic individuals that would escape diagnosis when the current guidelines are adopted or followed [13,14]. This becomes extremely prominent when considering the fact that $85 \%$ of a normotensive cohort with subclinical PA developed hypertension at 5-years of follow-up [15]. In line with these studies, administration of mineralocorticoid receptor antagonists (MRAs) has been shown to successfully control the blood pressure of patients with apparent essential hypertension, with their efficacy to be positively correlated with the levels of within the "normal" range aldosterone excess [16].

In light of these findings, Markou et al. investigated the role of ACTH, which has been predominantly regarded only as a minor regulator of aldosterone secretion in the development of PA. More specifically, they modified the standard fludrocortisone-saline suppression test (FST) by adding $2 \mathrm{mg}$ of dexamethasone on the last day of testing (fludrocortisone suppression test, FDST) in order to eliminate the ACTH effect on aldosterone secretion [17]. Strikingly, after applying the FDST test to a cohort of hypertensive patients with normal ARR result and adrenal morphology, 31\% of this cohort was diagnosed with PA and successfully treated [14]. In a subsequent study, we identified two novel germline mutations in the KCNJ5 gene in a cohort of patients without PA and normal adrenal CT, who exhibited ACTH-dependent aldosterone hypersecretion and responded to treatment 
with MRAs $[18,19]$. This work further expanded the clinical spectrum associated with KCNJ5 mutations and highlighted the importance of determining the genetic etiology of aldosterone hypersecretion in mild forms of primary aldosteronism towards earlier and targeted treatment.

\section{Genetics of Primary Aldosteronism}

PA can be either sporadic or familial. Sporadic cases of PA, Bilateral Adrenal Hyperplasia (BAH), and Aldosterone-Producing Adenomas (APAs), constitute the majority of PA cases $(95 \%)$.

On the other hand, only $5 \%$ of cases are familial, and four familial forms of PA, FH-I, FH-II, FH-III, and FH-IV, which are inherited in an autosomal dominant manner, have been recognized to date [20].

\section{Genetics of Sporadic Forms of Primary Aldosteronism}

Prior to the advent of NGS, studies on sporadic forms of PA primarily focused on genetic variants influencing the susceptibility to PA or acting as phenotype modifiers, such as CYP11B2, a-Adducin, and Bradykinin B2 Receptor gene polymorphism [21]. The development and widespread use of NGS shifted our approach and led to the identification of several somatic mutations in APAs that not only identified APA-driver genes but also furthered our understanding of the molecular mechanisms of aldosterone production regulation [21]. The majority of the somatic mutations in sporadic forms of PA reported to date (Table 2) have been identified into well-characterized ion channels and ATPases genes involved in aldosterone biosynthesis pathway, including potassium channels (KCNJ5), calcium channels (CACNA1D, CACNA1H), and ATPases (ATP1A1, ATP2B3) [22]. More recently, somatic mutations in CTNNB1, PRKACA, and ARMC5 genes (Table 2) have been implicated in the pathogenesis of APAs [22].

Table 2. Mutations reported in sporadic primary aldosteronism.

\begin{tabular}{|c|c|c|c|}
\hline Gene & Location (Hg19 *) & Somatic Mutations & $\begin{array}{l}\text { Sporadic } \\
\text { Germline } \\
\text { Mutations }\end{array}$ \\
\hline KCNJ5 & $11: 128,761,251-128,790,930$ & $\begin{array}{c}\text { p.R115W } \\
\text { p.T126R } \\
\text { p.A139-F142dup } \\
\text { p.F140L } \\
\text { p.144-G145insAI } \\
\text { p.E145Q } \\
\text { p.E145K } \\
\text { p.E145_E147delinsK } \\
\text { p.E147Q_T149_I150insTTT } \\
\text { p.T148I } \\
\text { p.T149insR } \\
\text { p.T149S } \\
\text { p.T149delinsTT } \\
\text { p.T149delinsMA } \\
\text { p.I150_G151insM } \\
\text { p.G151R } \\
\text { p.G153-G164dup } \\
\text { p.F154C } \\
\text { p.I157del } \\
\text { p.I57_E159del } \\
\text { p.I157K } \\
\text { p.T158A } \\
\text { p.L168R } \\
\text { p.G184E } \\
\text { p.G246K }\end{array}$ & $\begin{array}{c}\text { p.R52H } \\
\text { p.E145Q } \\
\text { p.G151R } \\
\text { p.G151E } \\
\text { p.Y152C } \\
\text { p.I157S } \\
\text { p.T158A } \\
\text { p.G246K } \\
\text { p.E247R }\end{array}$ \\
\hline
\end{tabular}


Table 2. Cont.

\begin{tabular}{|c|c|c|c|}
\hline Gene & Location (Hg19 *) & Somatic Mutations & $\begin{array}{l}\text { Sporadic } \\
\text { Germline } \\
\text { Mutations }\end{array}$ \\
\hline CACNA1D & $3: 53,529,076-53,846,492$ & $\begin{array}{l}\text { p.V259A } \\
\text { p.V309A } \\
\text { p.V401L } \\
\text { p.G403R } \\
\text { p.R619P } \\
\text { p.S652L } \\
\text { p.L655P } \\
\text { p.Y741C } \\
\text { p.F747L } \\
\text { p.F747C } \\
\text { p.F747V } \\
\text { p.V979N } \\
\text { p.P1336R } \\
\text { p.I750M } \\
\text { p.R990G } \\
\text { p.R993T } \\
\text { p.A998I } \\
\text { p.A998V } \\
\text { p.C1007R } \\
\text { p.I1015S } \\
\text { p.V1151F } \\
\text { p.I1152N } \\
\text { p.V1338M } \\
\text { p.V1353M }\end{array}$ & $\begin{array}{l}\text { p.I770M } \\
\text { p.G403R } \\
\text { p.F747L }\end{array}$ \\
\hline ATP1A1 & $1: 116,915,795-116,947,396$ & $\begin{array}{c}\text { p.G99R } \\
\text { p.F100L } \\
\text { p.P100_L104del) } \\
\text { p.L104R } \\
\text { p.V332G } \\
\text { p.I955_E960delinsK } \\
\text { p.960-963delp.A963S }\end{array}$ & \\
\hline ATP2B3 & $X: 152,801,580-152,848,387$ & $\begin{array}{l}\text { p.L425_V426del } \\
\text { p.V426_V427del } \\
\text { p.V424_L425del }\end{array}$ & \\
\hline CTNNB1 & $3: 41,240,942-41,281,939$ & $\begin{array}{c}\text { p.S33C } \\
\text { p.G34R } \\
\text { p.A39Efs*3 } \\
\text { p.S45P } \\
\text { p.S45F } \\
\text { p.V426G_V427Q_A428_L433del }\end{array}$ & \\
\hline CLCN2 & $3: 184,063,973-184,079,439$ & p.Gly24Asp & \\
\hline PRKACA & $19: 14,202,507-14,228,559$ & $\begin{array}{l}\text { p.His88Asp } \\
\text { p.Arg201Cys } \\
\text { p.Leu206Arg }\end{array}$ & \\
\hline ARMC5 & $16: 31,470,317-31,478,488$ & & $\begin{array}{l}\text { p.F14Y } \\
\text { p.L156F } \\
\text { p.I170V } \\
\text { p.G323A } \\
\text { p.R502H } \\
\text { p.P507L }\end{array}$ \\
\hline & & & $\begin{array}{l}\text { p.T643M } \\
\text { p.P826H } \\
\text { p.R898W }\end{array}$ \\
\hline
\end{tabular}




\subsection{KCNJ5 Mutations}

In 2011, Choi et al. identified two recurrent heterozygous mutations in the KCNJ5 gene (p.Gly151Arg and p.Leu168Arg) in 8/22 APA samples [23]. Subsequent studies revealed that KCNJ5 somatic mutations constitute the most frequent genetic defect in APAs, with their prevalence reaching $40-60 \%[24,25]$ in Caucasians and 70\% in Japanese patients [26]. Furthermore, higher frequencies have been reported in female compared with male patients (67\% vs. $44 \%$ respectively) [27]. The KCNJ5 (potassium inwardly rectifying channel, subfamily J, member 5 ) gene encodes the $G$ protein-activated inward rectifier potassium channels (Kir) 3.4, highly expressed in adrenal gromerulosa cells and important for maintaining the normal resting negative membrane potential of gromerulosa cells by mediating efflux of potassium ions. The mutations identified in APAs are located near the selectivity filter of the channel and abolish the $\mathrm{K}^{+}$selectivity of the channel that results in increased $\mathrm{Na}^{+}$influx, membrane depolarization, and opening of the voltagegated calcium channels [23]. The rise in intracellular $\mathrm{Ca}^{2+}$ concentration triggers the transcription of aldosterone synthase gene, CYP11B2, and leads to autonomous aldosterone hypersecretion [23].

Regarding the histological phenotype of KCNJ5-positive tumors, they are characterized by zona fasciculata (ZF)-like cell composition and by lower pre-contrast Hounsfield Units (H.U) units than tumors mutated in other genes [28]. KCNJ5-positive tumors tend to be larger compared to cases with other somatic mutations or non-mutated cases, often requiring unilateral adrenalectomy [28], and secrete high amounts of the steroid 18-oxocortisol that could serve as a biomarker to determine which APA patients might need surgery [29]. Considering the specific histopathologic phenotypes of KCNJ5-positive tumors, it has been suggested that young females with larger tumors and lower H.U units on CT scan, a profile that indicates the presence of KCNJ5 mutations, may avoid the procedure of adrenal vein sampling prior to surgery [28].

Transcriptomic analysis of APAs revealed that KCNJ5-positive tumors tend to exhibit lower levels of CYP11B2 expression and higher levels of CYP11B1 than CACNA1D/ATP1A1/ ATP2B3-positive tumors [30]. The relatively low levels of CYP11B2 expression in KCNJ5 tumors is compensated by their large tumor size, explaining the similar plasma aldosterone concentrations in APAs patients with other genetic mutations [31]. In some studies, patients with KCNJ5-positive tumors have been associated with a better surgical outcome and postoperative resolution of hypertension with the administration of limited number hypertensive drugs compared to patients with wild type KCNJ5 channels [32-34]. In vitro studies have shown that KCNJ5-mutated channels can be inhibited by macrolide antibiotics. Ongoing clinical trials evaluate the clinical effectiveness of two macrolides, clarithromycin, and roxithromycin, in the treatment of PA, and assess whether plasma aldosterone concentrations and blood pressure changes in response to these agents can be predictive of KCNJ5-positive tumors [35].

\subsection{CACNA1D Mutations}

By performing exome sequencing, two independent studies reported CACNA1D gene somatic mutations in $8 \%$ and $5 \%$ of APAs studied [36,37]. CACNA1D gene encodes for the pore-forming Cav1.3 subunit of the L-type voltage-gated calcium channel that contains 4 repeated domains (I-IV), each with 6 transmembrane segments (S1-S6) and a membrane-associated loop between S5 and S6. The S5 and S6 segments, together with the membrane-associated loop form the pore of the channel [29]. Electrophysiological studies showed that the identified somatic mutations cause an increase in calcium permeability of glomerulosa cells and a concomitant rise in aldosterone production either by shifting the activation to more negative potentials or by reducing the inactivation of the channel $[28,29]$. Compared to KCNJ5 mutations, CACNA1D mutations are more scattered throughout the protein and are detected in different regions involved in activation (S6 segment) and voltage sensing (S4 and S5 segment); therefore, a thorough sequencing of CACNA1D gene is recommended in patients with APAs. In some but not all studies, CACNA1D mutations 
have been linked with a glomerulosa-like phenotype [36,38], suggesting that these tumors derive from zona glumerolosa (ZG) cells [37]. In comparison with KCNJ5-positive tumors, CACNA1D-positive tumors are significantly smaller in size with higher H.U units on CT scan [28,37], and they have negative expression of CYP11B1 and higher expression of CYP11B2 [39]. In the study by Kitamoto et al. [40], it was reported that CACNA1D APAs with a predominant zona fasciculata composition display moderate autonomous aldosterone production compared to tumors with ATPase mutations [40]. Patients with CACNA1D mutations are more often males [36], older, and with a milder phenotype of hypokalemia than patients with tumors of different genetic background [33]. Calcium channel blocker administration has been proposed as a potential targeted treatment of this distinct cohort of patients, apart from the surgical resection of the affected adrenal glands, in severe cases [37].

\subsection{ATPA1 and ATPA2B3 Mutations}

Beuschein et al. [41] identified mutations in two members of the P-type ATPase gene family, namely ATP1A1 (coding the a1 subunit of the $\mathrm{Na}(+) / \mathrm{K}(+)$ ATPase) and ATP2B3 (coding for the plasma membrane $\mathrm{Ca}^{2+}$-ATPase, type 3 ) in three and two of the nine APAs studied, respectively [30]. Subsequently, the investigators demonstrated that variants clustered in the protein ion-binding domains of ATP1A1 and ATP2B3 cause increased sodium and protons conductance, leading to cell depolarization and enhanced aldosterone production, a mechanism similar to KCNJ5 mutations [28,42]. APAs with ATPase mutations, despite their relatively small sample size compared to CACNA1D adrenal lesions, have been associated with a more severe PA phenotype, marked by increased aldosterone production [40]. Furthermore, the number of hypertensive medications required for controlling the BP of patients with ATPase mutations has been reported to be higher than that of patients with KCNJ5-positive mutations [43]. Similar to CACNA1D-positive tumors, it has been shown by several studies that ATP1A1/ATP2B3-positive tumors display a ZG-like histological appearance $[41,44]$, and they are characterized by strong and weak expression of CYP11B2 and CYP11B1, respectively [41,44].

\subsection{CTNNB1, PRKACA, ARMC5, and CLCN2 Mutations}

Activating mutations in CTNNB1, the gene encoding beta-catenin, the final effector of WNT pathway, were reported in APAs by Åkerström et al. [45]. Although, the exact mechanism by which mutations in beta-catenin can lead to PA is unknown, this finding supports that sustained activation of WNT pathway leads to the formation of aldosteroneproducing lesions [32]. CTNNB1-positive tumors have larger adrenal lesion diameters compared to non-mutated tumors and are more prevalent in females, similar to KCNJ5positive tumors [28,45]. Rare causes of APAs $(1.6 \%)$ are somatic mutations in PRKACA (catalytic subunit of protein kinase A) gene, a gene mainly implicated in cortisol-producing adenomas. However, the exact pathophysiologic process leading to APA formation has not been fully elucidated for a group of cortisol co-secreting APAs [46]. The identified patients bearing PRKACA somatic mutations were treated with unilateral adrenalectomy, whereas postoperative administration of a limited number of antihypertensive drugs successfully controlled their BP. Germline variants predicted as damaging in Armadillo Repeat Containing Protein 5 (ARMC5) gene have been reported in African-American patients [47] with sporadic PA but not in Caucasian patients with PA [48]. Patients with tumors carrying ARMC5 variants presented with varying levels of hyperaldosteronism, low-renin hypertension, and decreased expression of CYP11B2 [47]. The lower expression of CYP11B2 was possibly compensated by the increased adrenocortical mass, leading to hyperaldosteronism [47]. Recently, a mutation in CLCN2 gene (p.Gly24Asp), associated with FH-II, was identified in a patient with APA [49]. 


\section{Genetics of Familial Forms of Primary Aldosteronism}

Familial hyperaldosteronism is a rare cause of PA and is categorized into four types, each one characterized by specific clinical features and genetic causes (Figure 1) (Table 3). However, a considerable proportion of cases with early-onset PA remains unsolved, indicating that new genes responsible for FH remain to be identified [50].

A) FH-I

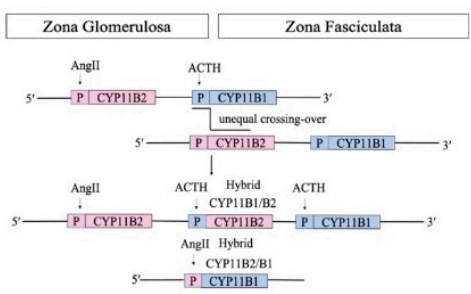

C) FH-III

KCNJ5

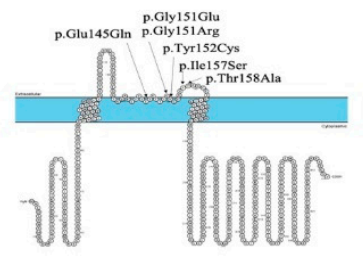

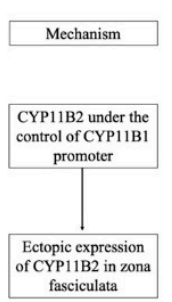
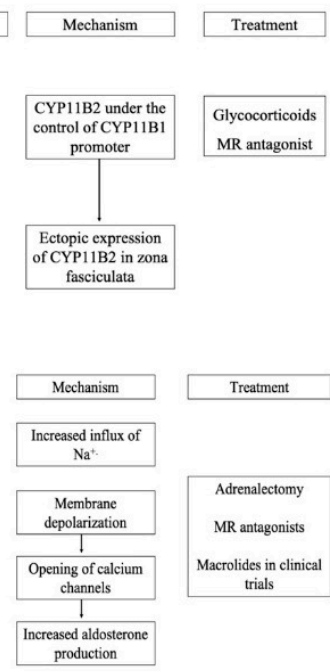

B) FH-II
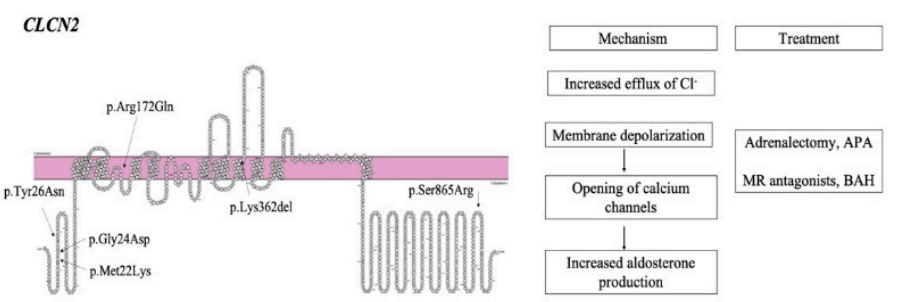

D) FH-IV

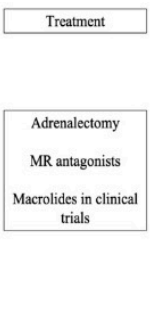

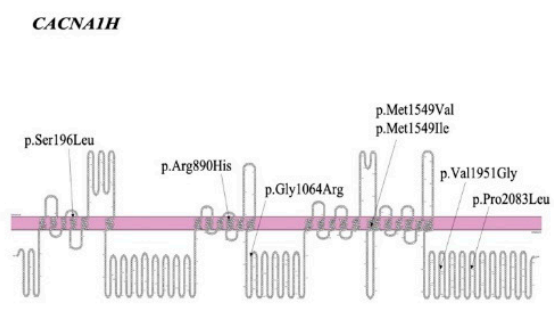

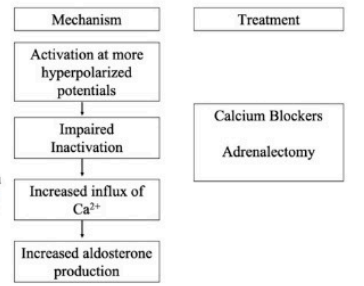

Figure 1. Pathogenetic mechanisms involved in familial forms of Primary Aldosteronism and treatment (A) FH-I is caused by an unequal crossover between CYP11B1 and CYP11B2 genes. (B) FH-II is caused by mutations in CLCN2 gene that lead to opening of calcium channels. (C) FH-III is caused by mutations in KCNJ5 gene. (D) FH-IV is caused by mutations in CACNA1H gene.

Table 3. Clinical characteristics of FH type I, II, III, and IV.

\begin{tabular}{ll}
\hline Familial Form of Primary Aldosteronism & Clinical Characteristics \\
\hline $\begin{array}{l}\text { Familial hyperaldosteronism type I, FH-I or } \\
\text { glucocorticoid-remediable aldosteronism }\end{array}$ & $\begin{array}{l}\text { Glucocorticoid-sensitive PATreated with } \\
\text { dexamethasone administrationAdrenal } \\
\text { hyperplasiaLow renin levelsIntracranial } \\
\text { aneurysm and hemorrhagic } \\
\text { strokeHypokalemiaNormotensive to severely } \\
\text { hypertensiveHybrid steroid levels }\end{array}$ \\
\hline Familial hyperaldosteronism type II & $\begin{array}{l}\text { Phenotype resembling sporadic forms of } \\
\text { PAHypokalemiaLow renin } \\
\text { levelsGlucocorticoid-insensitive PAAPAs or } \\
\text { Adrenal hyperplasia or bothNormotensive to } \\
\text { severely hypertensive }\end{array}$ \\
\hline Familial hyperaldosteronism type III & $\begin{array}{l}\text { Low renin levelsBilateral massive adrenal } \\
\text { hyperplasiaGlucocorticoid-insensitive } \\
\text { PAHypokalemiaSeverely hypertensive }\end{array}$ \\
\hline Familial hyperaldosteronism type IV & $\begin{array}{l}\text { Low renin levelsNormal adrenal } \\
\text { morphologyWide range of clinical phenotypes }\end{array}$ \\
\hline
\end{tabular}

\section{Familial Hyperaldosteronism Type I, FH-I}

The first familial form of PA, described by Sutherland et al. [51] in 1966, was initially referred to as glucocorticoid-remediable aldosteronism (GRA) because it was treated with dexamethasone. However, it was renamed FH-I after the identification of additional forms of FH. The molecular basis of FH-I was delineated more than two decades after its first 
description, by the work of Lifton et al. [52], who recognized as its cause the presence of a chimeric gene produced by an unequal crossing-over event between the promoter region of 11-beta hydroxylase gene (CYP11B1) that participates in cortisol biosynthesis and the coding regions of aldosterone synthase (CYP11B2) gene. As a result, aldosterone is ectopically synthesized in the adrenal zona fasciculata under the regulation of ACTH and not under the renin-angiotensin system (RAS) [39]. The diagnosis of FH-I is based on genetic testing for the presence of the chimeric gene, while the treatment involves MRAs or glucocorticoid administration [7].

\subsection{Familial Hyperaldosteronism Type II, FH-II}

FH-II, first described by Gordon et al. [53] in 1991, constitutes the most common subtype of $\mathrm{FH}$, with a prevalence of $1.2-6 \%$ [54], which is characterized by bilateral adrenal hyperplasia and/or the presence of adrenal lesions similar to sporadic PA. A linkage analysis showed an association of FH-II with the chromosome region 7p22 [55]. However, its genetic cause was unknown until recently. In 2018, two independent groups $[37,56]$ reported gain of function mutations in CLCN2 gene that encodes a voltage-gated chloride channel in kindreds with FH-II. CLCN2 is highly expressed in zona glomerulosa cells and is activated under hyperpolarized membrane potentials promoting aldosterone biosynthesis. CLCN2 mutations in FH-II patients cause increased chloride efflux leading to membrane depolarization at resting potential, opening of voltage-gated calcium channels, and enhanced aldosterone production $[37,43]$.

\subsection{Familial Hyperaldosteronism Type III, FH-III}

FH-III was initially described in 2008 in a father and two daughters who presented with early-onset severe hypertension, profound hypokalemia, overproduction of 18-oxocortisol and 18-hydroxycortisol and marked adrenal hyperplasia [57]. Soon thereafter, we reported a new family with FH-III, in which two affected members, a mother, and a daughter, presented with severe PA and massive bilateral adrenal hyperplasia caused by a novel point mutation of the KCNJ5 gene [58]. Both the index case and her mother presented in childhood with markedly elevated aldosterone concentrations, suppressed plasma renin activity, and early-onset severe hypertension refractory to treatment, which required bilateral adrenalectomy. Sequencing of the KCNJ5 gene revealed a single, heterozygous guanine to thymine ( $\mathrm{G}$ to $\mathrm{T}$ ) substitution at nucleotide position 470 , resulting in isoleucine to serine (I to S) substitution at amino acid position 157. This mutation results in loss of ion selectivity, cell membrane depolarization, increased $\mathrm{Ca}^{2+}$ entry in adrenal glomerulosa cells, and increased aldosterone synthesis [45]. The genetic cause of FH-III is attributed to germline mutations in KCNJ5 gene that alter the $\mathrm{K}^{+}$selectivity of the channel [20]. Patients with FH-III exhibit a broad spectrum of phenotypic variability from mild or moderate hypertension responsive to treatment, to resistant hypertension due to massive adrenal hyperplasia [59]. Notably, patients with the same inherited KCNJ5 mutation (G151R) but with different phenotypes and severity of hyperaldosteronism have been reported, indicating that KCNJ5 genotype is insufficient to explain phenotypic variability and that other genetic and/or environmental factors may influence the phenotype [46].

\subsection{Familial Hyperaldosteronism Type IV, FH-IV}

In an effort to delineate the genetic cause of PA cases with unknown etiology, Scholl et al. performed exome sequencing of 40 unrelated patients with early-onset hypertension ( $<10$ years) [60]. Five subjects were identified as carriers of a de novo germline mutation (p.Met1549Val) in CACNA1H gene, encoding the voltage-gated T-type calcium channel Cav3.2. Functional analysis showed that the mutation causes impaired inactivation and activation of the channel at more hyperpolarized potentials, inducing increased $\mathrm{Ca}^{2+}$ influx and aldosterone hypersecretion [47]. Subsequently, Danill et al. [48] reported germline CACNA1H mutations in PA patients with different forms of PA, from familial hyperaldosteronism to sporadic PA (APA presence) and early-onset hypertension associated 
with multiple developmental disorders [61]. These findings suggest that $C A C N A 1 H$ is a susceptibility gene for PA development with a wide range of phenotypic presentation [48].

\subsection{PA with Seizures and Neurological Abnormalities (PASNA)}

PASNA, a new form of PA characterized by early-onset PA, neurological abnormalities, and seizures, is caused by gain-of-function mutations in CACNA1D gene [29]. Two children with PASNA syndrome were found to harbor germline mutations in CACNA1D gene, and functional studies demonstrated that these mutations lead to activation of the channel at less depolarized potentials or affect deactivation of the channel [29]. Furthermore, another infant with autism and epilepsy, features similar to the phenotype of PASNA syndrome, was reported to carry a mutation in CACNA1D gene [62]. Interestingly, a patient with hyperinsulinemic hypoglycemia but with normal aldosterone concentrations has been reported to be heterozygous for p.G403D change, a mutation previously reported in a PASNA case with PA [63]. It is likely that the presence of genetic and environmental modifiers may account for the phenotypic discordance in the two patients [50].

\section{Conclusions}

During the last decade, the development and wide application of NGS technology led to the identification of several somatic and germline mutations associated with sporadic and familial forms of PA. Notably, all causative genes reported to date are involved in well-characterized pathways regulating aldosterone production, such as potassium and calcium-sensing pathways. These findings do not only define new disease-causing genes and improve our understanding of the pathophysiology behind aldosterone biosynthesis, but also open the door to the development of novel pharmacologic agents for the treatment of patients with PA. However, the clinical approach for the diagnosis of mild forms of PA needs to be updated to allow the early identification of patients with subclinical PA. Finally, it is imperative to unravel the genetic background of PA across its clinical spectrum, from mild to severe, which, in turn, will facilitate the appropriate management and treatment of primary aldosteronism, a much more prevalent syndrome than previously thought.

Funding: This study was funded by internal funds of the Division of Endocrinology and Metabolism, Biomedical Research Foundation of the Academy of Athens, Athens, Greece.

Institutional Review Board Statement: Not applicable.

Informed Consent Statement: Not applicable.

Data Availability Statement: Data sharing not applicable.

Conflicts of Interest: The authors declare no conflict of interest

\section{References}

1. Ezzati, M.; Lopez, A.D.; Rodgers, A.; Hoorn, S.V.; Murray, C.J.L. Selected major risk factors and global and regional burden of disease. Lancet 2002, 21, 613-619. [CrossRef]

2. Kearney, P.M.; Whelton, M.; Reynolds, K.; Muntner, P.; Whelton, P.K.; He, J. Global burden of hypertension: Analysis of worldwide data. Lancet 2005, 365, 217-223. [CrossRef]

3. Calhoun, D.A. Aldosteronism and hypertension. Clin. J. Am. Soc. Nephrol. 2006, 1, 1039-1045. [CrossRef] [PubMed]

4. Rossi, G.P.; Bisogni, V.; Bacca, A.V.; Belfiore, A.; Cesari, M.; Concistrè, A.; del Pinto, R.; Fabris, B.; Fallo, F.; Fava, C.; et al. The 2020 Italian Society of Arterial Hypertension (SIIA) practical guidelines for the management of primary aldosteronism. Int. J. Cardiol. Hypertens. 2020, 5. [CrossRef] [PubMed]

5. Rossi, G.P.; Bernini, G.; Caliumi, C.; Desideri, G.; Fabris, B.; Ferri, C.; Ganzaroli, C.; Giacchetti, G.; Letizia, C.; Maccario, M.; et al. A Prospective Study of the Prevalence of Primary Aldosteronism in 1125 Hypertensive Patients. J. Am. Coll. Cardiol. 2006, 48, 2293-2300. [CrossRef] [PubMed]

6. Calhoun, D.A. Hyperaldosteronism as a common cause of resistant hypertension. Annu. Rev. Med. 2013, 64, 233-247. [CrossRef] [PubMed]

7. Seccia, T.M.; Letizia, C.; Muiesan, M.L.; Lerco, S.; Cesari, M.; Bisogni, V.; Petramala, L.; Maiolino, G.; Volpin, R.; Rossi, G.P. Atrial fibrillation as presenting sign of primary aldosteronism: Results of the Prospective Appraisal on the Prevalence of Primary Aldosteronism in Hypertensive (PAPPHY) Study. J. Hypertens. 2020, 38, 332-339. [CrossRef] 
8. Milliez, P.; Girerd, X.; Plouin, P.F.; Blacher, J.; Safar, M.E.; Mourad, J.J. Evidence for an increased rate of cardiovascular events in patients with primary aldosteronism. J. Am. Coll. Cardiol. 2005, 45, 1243-1248. [CrossRef] [PubMed]

9. Lim, Y.Y.; Shen, J.; Fuller, P.J.; Yang, J. Current pattern of primary aldosteronism diagnosis: Delayed and complicated. Aust. J. Gen. Pract. 2018, 47, 712-718. [CrossRef]

10. Funder, J.W.; Carey, R.M.; Mantero, F.; Murad, M.H.; Reincke, M.; Shibata, H.; Stowasser, M.; Young, W.F. The management of primary aldosteronism: Case detection, diagnosis, and treatment: An endocrine society clinical practice guideline. J. Clin. Endocrinol. Metab. 2016, 101, 1889-1916. [CrossRef]

11. Monticone, S.; Burrello, J.; Tizzani, D.; Bertello, C.; Viola, A.; Buffolo, F.; Gabetti, L.; Mengozzi, G.; Williams, T.A.; Rabbia, F.; et al. Prevalence and Clinical Manifestations of Primary Aldosteronism Encountered in Primary Care Practice. J. Am. Coll. Cardiol. 2017, 69, 1811-1820. [CrossRef]

12. Piaditis, G.P.; Kaltsas, G.; Markou, A.; Chrousos, G.P. Five Reasons for the Failure to Diagnose Aldosterone Excess in Hypertension. Horm. Metab. Res. 2020, 52, 827-833. [CrossRef]

13. Brown, J.M.; Siddiqui, M.; Calhoun, D.A.; Carey, R.M.; Hopkins, P.N.; Williams, G.H.; Vaidya, A. The Unrecognized Prevalence of Primary Aldosteronism: A Cross-sectional Study. Ann. Intern. Med. 2020. [CrossRef]

14. Piaditis, G.; Markou, A.; Papanastasiou, L.; Androulakis, I.I.; Kaltsas, G. Progress in aldosteronism: A review of the prevalence of primary aldosteronism in pre-hypertension and hypertension. Eur. J. Endocrinol. 2015, 172, R191-R203. [CrossRef] [PubMed]

15. Markou, A.; Pappa, T.; Kaltsas, G.; Gouli, A.; Mitsakis, K.; Tsounas, P.; Prevoli, A.; Tsiavos, V.; Papanastasiou, L.; Zografos, G.; et al. Evidence of primary aldosteronism in a predominantly female cohort of normotensive individuals: A very high odds ratio for progression into arterial hypertension. J. Clin. Endocrinol. Metab. 2013, 98, 1409-1416. [CrossRef] [PubMed]

16. Williams, B.; MacDonald, T.M.; Morant, S.V.; Webb, D.J.; Sever, P.; McInnes, G.T.; Ford, I.; Cruickshank, J.K.; Caulfield, M.J.; Padmanabhan, S.; et al. Endocrine and haemodynamic changes in resistant hypertension, and blood pressure responses to spironolactone or amiloride: The PATHWAY-2 mechanisms substudies. Lancet Diabetes Endocrinol. 2018, 6, 464-475. [CrossRef]

17. Gouli, A.; Kaltsas, G.; Tzonou, A.; Markou, A.; Androulakis, I.I.; Ragkou, D.; Vamvakidis, K.; Zografos, G.; Kontogeorgos, G.; Chrousos, G.P.; et al. High prevalence of autonomous aldosterone secretion among patients with essential hypertension. Eur. J. Clin. Invest. 2011, 41, 1227-1236. [CrossRef] [PubMed]

18. Markou, A.; Sertedaki, A.; Kaltsas, G.; Androulakis, I.I.; Marakaki, C.; Pappa, T.; Gouli, A.; Papanastasiou, L.; Fountoulakis, S.; Zacharoulis, A.; et al. Stress-induced aldosterone hyper-secretion in a substantial subset of patients with essential hypertension. $J$. Clin. Endocrinol. Metab. 2015, 100, 2857-2864. [CrossRef]

19. Sertedaki, A.; Markou, A.; Vlachakis, D.; Kossida, S.; Campanac, E.; Hoffman, D.A.; de la Sierra, M.L.; Xekouki, P.; Stratakis, C.A.; Kaltsas, G.; et al. Functional characterization of two novel germline mutations of the KCNJ5 gene in hypertensive patients without primary aldosteronism but with ACTH-dependent aldosterone hypersecretion. Clin. Endocrinol. 2016, 85, 845-851. [CrossRef]

20. Monticone, S.; Buffolo, F.; Tetti, M.; Veglio, F.; Pasini, B.; Mulatero, P. Genetics in Endocrinology: The expanding genetic horizon of primary aldosteronism. Eur. J. Endocrinol. 2018, 178, R101-R111. [CrossRef]

21. Monticone, S.; Else, T.; Mulatero, P.; Williams, T.A.; Rainey, W.E. Understanding primary aldosteronism: Impact of next generation sequencing and expression profiling. Mol. Cell. Endocrinol. 2015, 399, 311-320. [CrossRef] [PubMed]

22. Fernandes-Rosa, F.L.; Boulkroun, S.; Zennaro, M.C. Genetic and Genomic Mechanisms of Primary Aldosteronism. Trends Mol. Med. 2020, 26, 819-832. [CrossRef] [PubMed]

23. Choi, M.; Scholl, U.I.; Yue, P.; Björklund, P.; Zhao, B.; Nelson-Williams, C.; Ji, W.; Cho, Y.; Patel, A.; Men, C.J.; et al. K+ channel mutations in adrenal aldosterone-producing adenomas and hereditary hypertension. Science 2011, 331, 768-772. [CrossRef]

24. Åkerström, T.; Crona, J.; Verdugo, A.D.; Starker, L.F.; Cupisti, K.; Willenberg, H.S.; Knoefel, W.T.; Saeger, W.; Feller, A.; Ip, J.; et al. Comprehensive re-sequencing of adrenal aldosterone producing lesions reveal three somatic mutations near the KCNJ5 potassium channel selectivity filter. PLoS ONE 2012, 7, e41926. [CrossRef]

25. Boulkroun, S.; Beuschlein, F.; Rossi, G.P.; Golib-Dzib, J.F.; Fischer, E.; Amar, L.; Mulatero, P.; Samson-Couterie, B.; Hahner, S.; Quinkler, M.; et al. Prevalence, clinical, and molecular correlates of KCNJ5 mutations in primary aldosteronism. Hypertension 2012, 59, 592-598. [CrossRef] [PubMed]

26. Okamura, T.; Nakajima, Y.; Katano-Toki, A.; Horiguchi, K.; Matsumoto, S.; Yoshino, S.; Yamada, E.; Tomaru, T.; Ishii, S.; Saito, T.; et al. Characteristics of japanese aldosterone-producing adenomas with KCNJ5 mutations. Endocr. J. 2017. [CrossRef]

27. Lenzini, L.; Rossitto, G.; Maiolino, G.; Letizia, C.; Funder, J.W.; Rossi, G.P. A meta-analysis of somatic KCNJ5 K ${ }^{+}$channel mutations in 1636 patients with an aldosterone-producing adenoma. J. Clin. Endocrinol. Metab. 2015, 100, E1089-E1095. [CrossRef] [PubMed]

28. Scholl, U.I.; Healy, J.M.; Thiel, A.; Fonseca, A.L.; Brown, T.C.; Kunstman, J.W.; Horne, M.J.; Dietrich, D.; Riemer, J.; Kücükköylü, S.; et al. Novel somatic mutations in primary hyperaldosteronism are related to the clinical, radiological and pathological phenotype. Clin. Endocrinol. 2015, 83, 779-789. [CrossRef]

29. Williams, T.A.; Peitzsch, M.; Dietz, A.S.; Dekkers, T.; Bidlingmaier, M.; Riester, A.; Treitl, M.; Rhayem, Y.; Beuschlein, F.; Lenders, J.W.M.; et al. Genotype-Specific Steroid Profiles Associated With Aldosterone-Producing Adenomas. Hypertension 2016, 67, 139-145. [CrossRef] [PubMed]

30. Backman, S.; Åkerström, T.; Maharjan, R.; Cupisti, K.; Willenberg, H.S.; Hellman, P.; Björklund, P. RNA Sequencing Provides Novel Insights into the Transcriptome of Aldosterone Producing Adenomas. Sci. Rep. 2019, 9, 6269. [CrossRef] [PubMed] 
31. Williams, T.A.; Monticone, S.; Schack, V.R.; Stindl, J.; Burrello, J.; Buffolo, F.; Annaratone, L.; Castellano, I.; Beuschlein, F.; Reincke, M.; et al. Somatic ATP1A1, ATP2B3, and KCNJ5 mutations in aldosterone-producing adenomas. Hypertension 2014, 63, 188-195. [CrossRef]

32. Arnesen, T.; Glomnes, N.; Strømsøy, S.; Knappskog, S.; Heie, A.; Akslen, L.A.; Grytaas, M.; Varhaug, J.E.; Gimm, O.; Brauckhoff, M. Outcome after surgery for primary hyperaldosteronism may depend on KCNJ5 tumor mutation status: A population-based study from Western Norway. Langenbeck's Arch. Surg. 2013, 398, 869-874. [CrossRef] [PubMed]

33. Wu, V.C.; Huang, K.H.; Peng, K.Y.; Tsai, Y.C.; Wu, C.H.; Wang, S.M.; Yang, S.Y.; Lin, L.Y.; Chang, C.C.; Lin, Y.H.; et al. Prevalence and clinical correlates of somatic mutation in aldosterone producing adenoma-Taiwanese population. Sci. Rep. 2015, 5, 11396. [CrossRef]

34. Nanba, K.; Omata, K.; Gomez-Sanchez, C.E.; Stratakis, C.A.; Demidowich, A.P.; Suzuki, M.; Thompson, L.D.R.; Cohen, D.L.; Luther, J.M.; Gellert, L.; et al. Genetic characteristics of aldosterone-producing adenomas in blacks. Hypertension 2019, 73, 885-892. [CrossRef]

35. Maiolino, G.; Ceolotto, G.; Battistel, M.; Barbiero, G.; Cesari, M.; Amar, L.; Caroccia, B.; Padrini, R.; Azizi, M.; Rossi, G.P. Macrolides for KCNJ5-mutated aldosterone-producing adenoma (MAPA): Design of a study for personalized diagnosis of primary aldosteronism. Blood Press. 2018, 27, 200-205. [CrossRef]

36. Azizan, E.A.B.; Poulsen, H.; Tuluc, P.; Zhou, J.; Clausen, M.V.; Lieb, A.; Maniero, C.; Garg, S.; Bochukova, E.G.; Zhao, W.; et al. Somatic mutations in ATP1A1 and CACNA1D underlie a common subtype of adrenal hypertension. Nat. Genet. 2013, 45, 1055-1060. [CrossRef]

37. Scholl, U.I.; Goh, G.; Stölting, G.; de Oliveira, R.C.; Choi, M.; Overton, J.D.; Fonseca, A.L.; Korah, R.; Starker, L.F.; Kunstman, J.W.; et al. Somatic and germline CACNA1D calcium channel mutations in aldosterone-producing adenomas and primary aldosteronism. Nat. Genet. 2013, 45, 1050-1054. [CrossRef]

38. Dekkers, T.; Meer, M.T.; Lenders, J.W.M.; Hermus, A.R.M.; Kool, L.S.; Langenhuijsen, J.F.; Nishimoto, K.; Ogishima, T.; Mukai, K.; Azizan, E.A.B.; et al. Adrenal nodularity and somatic mutations in primary aldosteronism: One node is the culprit? J. Clin. Endocrinol. Metab. 2014, 99, E1341-E1345. [CrossRef] [PubMed]

39. Akerström, T.; Willenberg, H.S.; Cupisti, K.; Ip, J.; Backman, S.; Moser, A.; Maharjan, R.; Robinson, B.; Iwen, K.A.; Dralle, H.; et al. Novel somatic mutations and distinct molecular signature in aldosterone-producing adenomas. Endocr. Relat. Cancer 2015, 22, 735-744. [CrossRef] [PubMed]

40. Kitamoto, T.; Suematsu, S.; Yamazaki, Y.; Nakamura, Y.; Sasano, H.; Matsuzawa, Y.; Saito, J.; Omura, M.; Nishikawa, T. Clinical and steroidogenic characteristics of aldosterone-producing adenomas with ATPase or CACNA1D gene mutations. J. Clin. Endocrinol. Metab. 2016, 101, 494-503. [CrossRef]

41. Beuschlein, F.; Boulkroun, S.; Osswald, A.; Wieland, T.; Nielsen, H.N.; Lichtenauer, U.D.; Penton, D.; Schack, V.R.; Amar, L.; Fischer, E.; et al. Somatic mutations in ATP1A1 and ATP2B3 lead to aldosterone-producing adenomas and secondary hypertension. Nat. Genet. 2013, 45, 440-444. [CrossRef]

42. Tauber, P.; Aichinger, B.; Christ, C.; Stindl, J.; Rhayem, Y.; Beuschlein, F.; Warth, R.; Bandulik, S. Cellular pathophysiology of an adrenal adenoma-associated mutant of the plasma membrane $\mathrm{Ca}^{2+}$-ATPase ATP2B3. Endocrinology 2016, 157, $2489-2499$. [CrossRef]

43. Tan, G.C.; Negro, G.; Pinggera, A.; Laim, N.M.S.T.; Rose, I.M.; Ceral, J.; Ryska, A.; Chin, L.K.; Kamaruddin, N.A.; Mokhtar, N.M.; et al. Aldosterone-Producing Adenomas: Histopathology-Genotype Correlation and Identification of a Novel CACNA1D Mutation. Hypertension 2017, 70, 129-136. [CrossRef]

44. Monticone, S.; Castellano, I.; Versace, K.; Lucatello, B.; Veglio, F.; Gomez-Sanchez, C.E.; Williams, T.A.; Mulatero, P. Immunohistochemical, genetic and clinical characterization of sporadic aldosterone-producing adenomas. Mol. Cell. Endocrinol. 2015, 411, 146-154. [CrossRef]

45. Åkerström, T.; Maharjan, R.; Willenberg, H.S.; Cupisti, K.; Ip, J.; Moser, A.; Stålberg, P.; Robinson, B.; Iwen, K.A.; Dralle, H.; et al. Activating mutations in CTNNB1 in aldosterone producing adenomas. Sci. Rep. 2016, 6, 19546. [CrossRef]

46. Rhayem, Y.; Perez-Rivas, L.G.; Dietz, A.; Bathon, K.; Gebhard, C.; Riester, A.; Mauracher, B.; Gomez-Sanchez, C.; Eisenhofer, G.; Schwarzmayr, T.; et al. PRKACA somatic mutations are rare findings in aldosterone-producing adenomas. J. Clin. Endocrinol. Metab. 2016, 101, 3010-3017. [CrossRef]

47. Zilbermint, M.; Xekouki, P.; Faucz, F.R.; Berthon, A.; Gkourogianni, A.; Schernthaner-Reiter, M.H.; Batsis, M.; Sinaii, N.; Quezado, M.M.; Merino, M.; et al. Primary aldosteronism and ARMC5 variants. J. Clin. Endocrinol. Metab. 2015, 100, E900-E909. [CrossRef]

48. Mulatero, P.; Schiavi, F.; Williams, T.A.; Monticone, S.; Barbon, G.; Opocher, G.; Fallo, F. ARMC5 mutation analysis in patients with primary aldosteronism and bilateral adrenal lesions. J. Hum. Hypertens. 2016, 30, 374-378. [CrossRef]

49. Dutta, R.K.; Arnesen, T.; Heie, A.; Walz, M.; Alesina, P.; Söderkvist, P.; Gimm, O. A somatic mutation in CLCN2 identified in a sporadic aldosterone-producing adenoma. Eur. J. Endocrinol. 2019, 181, K37-K41. [CrossRef]

50. Fernandes-Rosa, F.L.; Daniil, G.; Orozco, I.J.; Göppner, C.; El Zein, R.; Jain, V.; Boulkroun, S.; Jeunemaitre, X.; Amar, L.; Lefebvre, $\mathrm{H}$; ; et al. A gain-of-function mutation in the CLCN2 chloride channel gene causes primary aldosteronism. Nat. Genet. 2018, 50, 355-361. [CrossRef] [PubMed]

51. Sutherland, D.J.; Ruse, J.L.; Laidlaw, J.C. Hypertension, increased aldosterone secretion and low plasma renin activity relieved by dexamethasone. Can. Med. Assoc. J. 1966, 95, 1109-1119. 
52. Lifton, R.P.; Dluhy, R.G.; Powers, M.; Rich, G.M.; Cook, S.; Ulick, S.; Lalouel, J.M. A chimaeric 11 beta-hydroxylase/aldosterone synthase gene causes glucocorticoid-remediable aldosteronism and human hypertension. Nature 1992, 355, 262-265. [CrossRef]

53. Gordon, R.D.; Stowasser, M.; Tunny, T.J.; Klemm, S.A.; Finn, W.L.; Krek, A.L. Clinical and Pathological Diversity of Primary Aldosteronism, Including a New Familial Variety. Clin. Exp. Pharmacol. Physiol. 1991, 18, 283-286. [CrossRef]

54. Mulatero, P.; Tizzani, D.; Viola, A.; Bertello, C.; Monticone, S.; Mengozzi, G.; Schiavone, D.; Williams, T.A.; Einaudi, S.; La Grotta, A.; et al. Prevalence and characteristics of familial hyperaldosteronism: The PATOGEN study (Primary aldosteronism in TOrino-GENetic forms). Hypertension 2011, 58, 797-803. [CrossRef]

55. Lafferty, A.R.; Torpy, D.J.; Stowasser, M.; Taymans, S.E.; Lin, J.P.; Huggard, P.; Gordon, R.D.; Stratakis, C.A. A novel genetic locus for low renin hypertension: Familial hyperaldosteronism type II maps to chromosome 7 (7p22). J. Med. Genet. 2000, 37. [CrossRef] [PubMed]

56. Scholl, U.I.; Stölting, G.; Schewe, J.; Thiel, A.; Tan, H.; Nelson-Williams, C.; Vichot, A.A.; Jin, S.C.; Loring, E.; Untiet, V.; et al. CLCN2 chloride channel mutations in familial hyperaldosteronism type II. Nat. Genet. 2018, 50, 349-354. [CrossRef]

57. Geller, D.S.; Zhang, J.; Wisgerhof, M.V.; Shackleton, C.; Kashgarian, M.; Lifton, R.P. A novel form of human mendelian hypertension featuring nonglucocorticoid-remediable aldosteronism. J. Clin. Endocrinol. Metab. 2008, 93, 3117-3123. [CrossRef]

58. Charmandari, E.; Sertedaki, A.; Kino, T.; Merakou, C.; Hoffman, D.A.; Hatch, M.M.; Hurt, D.E.; Lin, L.; Xekouki, P.; Stratakis, C.A.; et al. A novel point mutation in the KCNJ5 gene causing primary hyperaldosteronism and early-onset autosomal dominant hypertension. J. Clin. Endocrinol. Metab. 2012, 97, E1532-E1539. [CrossRef]

59. Adachi, M.; Muroya, K.; Asakura, Y.; Sugiyama, K.; Homma, K.; Hasegawa, T. Discordant genotype-phenotype correlation in familial hyperaldosteronism type III with KCNJ5 gene mutation: A patient report and review of the literature. Horm. Res. Paediatr. 2014, 82, 138-142. [CrossRef]

60. Scholl, U.I.; Stölting, G.; Nelson-Williams, C.; Vichot, A.A.; Choi, M.; Loring, E.; Prasad, M.L.; Goh, G.; Carling, T.; Juhlin, C.C.; et al. Recurrent gain of function mutation in calcium channel CACNA1H causes early-onset hypertension with primary aldosteronism. eLife 2015. [CrossRef]

61. Daniil, G.; Fernandes-Rosa, F.L.; Chemin, J.; Blesneac, I.; Beltrand, J.; Polak, M.; Jeunemaitre, X.; Boulkroun, S.; Amar, L.; Strom, T.M.; et al. CACNA1H Mutations Are Associated With Different Forms of Primary Aldosteronism. EBioMedicine 2016, 13, 225-236. [CrossRef] [PubMed]

62. Pinggera, A.; Mackenroth, L.; Rump, A.; Schallner, J.; Beleggia, F.; Wollnik, B.; Striessnig, J. New gain-of-function mutation shows CACNA1D as recurrently mutated gene in autism spectrum disorders and epilepsy. Hum. Mol. Genet. 2017, 26, $2923-2932$. [CrossRef] [PubMed]

63. Flanagan, S.E.; Vairo, F.; Johnson, M.B.; Caswell, R.; Laver, T.W.; Lango Allen, H.; Hussain, K.; Ellard, S. A CACNA1D mutation in a patient with persistent hyperinsulinaemic hypoglycaemia, heart defects, and severe hypotonia. Pediatr. Diabetes 2017, 18, 320-323. [CrossRef] [PubMed] 